\title{
Performance of a campus photovoltaic electric vehicle charging station in a temperate climate
}

\author{
Ayda Esfandyari \\ Technological University Dublin, ayda.esfandyari@tudublin.ie \\ Brian Norton \\ Technological University Dublin, brian.norton@tudublin.ie \\ Michael Conlon \\ Technological University Dublin, michael.conlon@tudublin.ie
}

See next page for additional authors

Follow this and additional works at: https://arrow.tudublin.ie/engscheleart2

Part of the Power and Energy Commons

\section{Recommended Citation \\ Ayda Esfandyari, Brian Norton, Michael Conlon, Sarah J. McCormack, Performance of a campus photovoltaic electric vehicle charging station in a temperate climate, Solar Energy, Volume 177, 2019, Pages 762-771, ISSN 0038-092X, DOI: 10.1016/j.solener.2018.12.005.}

This Article is brought to you for free and open access by the School of Electrical and Electronic Engineering at ARROW@TU Dublin. It has been accepted for inclusion in Articles by an authorized administrator of ARROW@TU Dublin. For more information, please contact arrow.admin@tudublin.ie, aisling.coyne@tudublin.ie, gerard.connolly@tudublin.ie.

Funder: Technological University Dublin

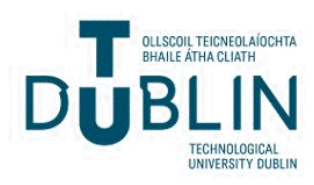




\section{Authors}

Ayda Esfandyari, Brian Norton, Michael Conlon, and Sarah J. McCormack

This article is available at ARROW@TU Dublin: https://arrow.tudublin.ie/engscheleart2/269 


\title{
Performance of a campus photovoltaic electric vehicle charging station in a temperate climate
}

\author{
Ayda Esfandyari $^{\mathrm{a}, *}$, Brian Norton ${ }^{\mathrm{a}}$, Michael Conlon ${ }^{\mathrm{a}}$, Sarah J. McCormack ${ }^{\mathrm{b}}$ \\ ${ }^{\text {a }}$ School of Electrical and Electronic Engineering, Dublin Energy Lab (DEL), Dublin Institute of Technology, Dublin 7, Ireland \\ ${ }^{\mathrm{b}}$ Department of Civil, Structural and Environmental Engineering, Trinity College Dublin, Dublin 2, Ireland
}

\section{A R T I C L E I N F O}

\section{Keywords:}

Photovoltaics

Battery energy storage

AC coupled PV system

Electric vehicles (EV)

Energy management controller

\begin{abstract}
A B S T R A C T
A photovoltaic (PV) array can be combined with battery energy storage to satisfy the electrical demand of lightweight electric vehicles. Measured solar resource and vehicle energy consumption, together with locational, mechanical and electrical constraints were used to design a vehicle charging station comprised of a $63 \mathrm{~m}^{2}$ $10.5 \mathrm{~kW}$ AC PV array, with a $9.6 \mathrm{kWh}$ lithium-ion battery. PV output, battery charge and discharge, electricity flows were monitored over one year. Deviations between measured and calculated annual AC generation averaged to $14 \%$. Average annual direct consumption, self-consumption and system self-sufficiency were $8.47 \%$, $30.3 \%$ and $74.36 \%$ respectively.
\end{abstract}

\section{Introduction}

A photovoltaic (PV) array with battery storage for powering lightweight electrical vehicle (EV) is examined with the aim to maximise self-consumption and autonomy.

A smart charging infrastructure can use solar PV (Tamis et al., 2017), to provide sustainable and $\mathrm{CO}_{2}$ savings in both electricity generation and consumption for charging electric vehicles (EV). There is limited research on the holistic design, operation and optimisation of self-generating autonomous campus PV EV charging stations, especially in temperate climates. The advantage of an AC coupled battery base campus PV EV charging station connected to the university's micro-grid lies in its dispatch strategy, in which PV output not used directly for EV or battery storage charging is not wasted, it can be utilised to balance supplementary demands met by the campus micro grid. Any surplus PV generation spilled in the campus micro-grid only has economic gains equal to the grid tariff, as microgeneration feed-in tariffs (FIT) have declined in Germany (Weniger et al., 2014) and Ireland (SEAI, 2017).

\section{Background literature}

Kineavy and Duffy (2014) and Foley et al. (2010) have provided comprehensive reviews of grid-to-vehicle charging. International standards for EV infrastructure classify standard plugs and sockets for EV charging by rated power and charge with technical specifications for residential slow charging, public quick charging and off-board fast charging now available (Tie and Tan, 2013; Torreglosa et al., 2016). The use of PV generated electricity for EV charging is well established (Goli and Shireen, 2015; Tulpule et al., 2013). A smart charging infrastructure achieves greater grid stability with PV generation by taking into account PV generation, charging times, energy curtailment and load shifting (Goli and Shireen, 2014; Tamis et al., 2017).

The efficiency with which PV systems convert solar radiation into electricity is affected by weather conditions, system operation and the conditions of system components (Mondol et al., 2006a). A PV installation is designated to harness available solar energy resource in a specific location to satisfy an electrical load profile, using specifications of selected PV array, balance- of-system components (BOS) available within budget (Hasapis et al., 2017; TU Delft, 2018). The interrelationships between factors determining grid-connected PV system sizing are shown in Fig. 1 (Mondol et al., 2006b). Annual performance indicators for PV plants include DC and AC array output, array yield, final yield, reference yield, performance ratio, capacity factor, system efficiency, array capture loss and system losses (Ayompe et al., 2011a; Kymakis et al., 2009; Mondol et al., 2006a; Sundaram and Babu, 2015). Monitored data can be compared with performance predictions from simulations (Mondol et al., 2007).

Battery storage allows for PV generated energy to be stored for use when (i): there is no load and/ or when grid feed-in electricity prices are low, and (ii): solar energy is not present or the grid buying tariffs are higher (Van Der Kam and Van Sark, 2015). Several studies have considered battery integration and battery management in grid-

\footnotetext{
* Corresponding author.

E-mail addresses: ayda.esfandyari@dit.ie (A. Esfandyari), president@dit.ie (B. Norton), michael.conlon@dit.ie (M. Conlon), mccorms1@tcd.ie (S.J. McCormack).
} 


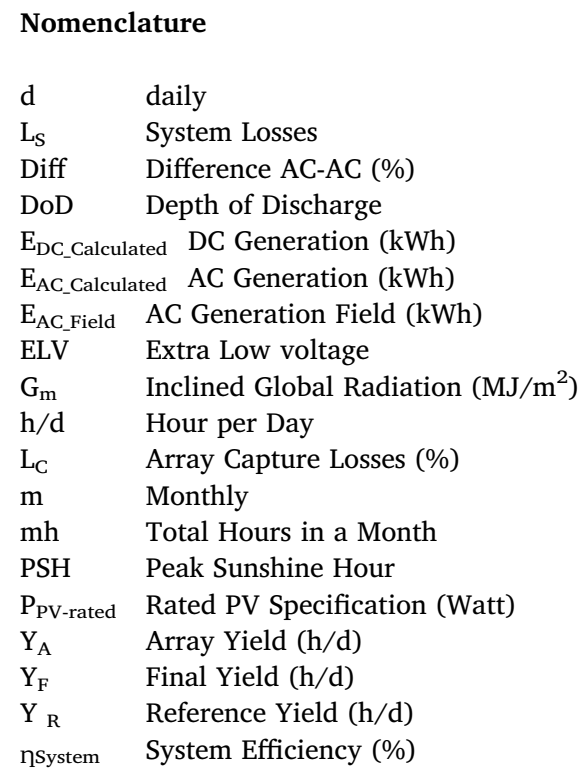

\section{Abbreviations}

$\begin{array}{ll}\text { AC } & \text { Alternative Current } \\ \text { BEM } & \text { Battery Energy Management } \\ \text { BEVs } & \text { Battery Electric Vehicles } \\ \text { BOS } & \text { Balance of System } \\ \text { CF } & \text { Capacity Factor (h/d) } \\ \text { CS } & \text { Radio Control Smart Socket } \\ \text { DC } & \text { Direct Current } \\ \text { EC } & \text { Energy Controller } \\ \text { EMET } & \text { PV Energy Meter } \\ \text { ELV } & \text { Extra Low voltage } \\ \text { EVs } & \text { Electric Vehicles } \\ \text { GM } & \text { Grid Meter } \\ \text { LEVs } & \text { Light weight Electric Vehicles } \\ \text { Li-ion } & \text { Lithium-ion } \\ \text { RC } & \text { Remote Control Battery Management } \\ \text { PV } & \text { Photovoltaic } \\ \text { PR } & \text { Performance ratio (\%) } \\ \text { SOC } & \text { State of Charge }\end{array}$

connected PV systems (Lorenzi and Silva, 2016; Riffonneau et al., 2011; Van Der Stelt et al., 2018). Economic optimal performance (Kusakana, 2017) with increased self-consumption can be achieved via appropriate battery management (Luthander et al., 2015). Self-consumption ratio is that between the PV energy used directly (to serve either the load or charge a battery) and the overall PV energy produced (Weniger et al., 2014). Self-consumption ratio is influenced by the power rating of the PV array, the available solar energy resource as well as daily and load demand patterns (Bertsch et al., 2017).

Battery storage combined with demand side management can be used to maximize self-consumption ratio; by using a Mixed Integer Linear Programming (MILP) technique to minimize grid dependency (Van Der Stelt et al., 2018) or a dynamic optimization strategy for power flow management in a grid-connected battery system (Riffonneau et al., 2011). Self-sufficiency ratio indicates the extent of grid independency (Luthander et al., 2015), being the demand supplied by battery discharge or direct consumption to total load demand. Numerous studies (Bertsch et al., 2017; Delfanti et al., 2015; Mouli et al., 2016; Nyholm et al., 2016; Speidel and Bräunl, 2016; Weniger et al., 2014) have shown that using battery storage and demand-side management enhances self-consumption and thus self-sufficiency of dwellings with PV.

Numerous studies have examined PV EV charging (Bdwawi et al., 2015; Birnie, 2009; Mouli et al., 2016, 2015; University of Iowa, 2018; Van Der Kam and Van Sark, 2015; Wanitschke et al., 2017). Mouli (2018); Mouli et al. (2015) when comparing different PV EV charging system architectures and power converter topologies, found a threeport modular power converter that established bidirectional EV grid connection was a feasible option as it enabled interconnecting PV and EV on DC with connection to the AC grid. In a $10 \mathrm{~kW}$ workplace PV EV bidirectional dynamic charging station, due to the variations of summer and winter PV production, grid extension only became viable for a $30 \%$ oversized PV array in comparison to its inverter (Mouli et al., 2016). Numerous examples of advanced energy managements for EV urban mobility control charging infrastructure are available (Bhatti et al., 2016; Codani et al., 2015; Gurkaynak et al., 2009; Kineavy and Duffy, 2014; Mouli et al., 2016; Roggia et al., 2011)

Bhatti et.al. (2016) in a review of PV EV charging methods, power converter topologies and control mechanisms for both standalone and grid connected PV charging infrastructures, highlighted the importance of optimized energy management systems, while acknowledging the advantages of heuristic rule-based charging strategies for energy management. Kineavy and Duffy (2014) assessed the feasibility of a PV charging station to accommodate four EVs (Nissan Leaf), travelling $50 \mathrm{~km}$ throughout the day in Galway in Ireland through a $6.5 \mathrm{~kW}$ PV infrastructure, considering both DC and AC conversion efficiencies. The control strategy adopted attempted to maximize the PV energy usage, reduce the impact on the $\mathrm{AC}$ grid, while meeting the demand of the $\mathrm{EV}$ batteries. Codani et al. (2015) examined smart charging strategies in France, taking into account regional characteristics, PV and wind resources and energy management systems (EMS) for control of EV charging patterns. They highlighted the advantages of EV charging with EMS control, especially in sunnier regions. A micro grid incorporating a $2.34 \mathrm{~kW}$ peak PV and a $4.4 \mathrm{~kW}$ biodiesel generator, for supplying $12 \mathrm{~kW}$ residential AC/DC type load as well as a $2.5 \mathrm{~kW}$ EV incorporated energy storage (Roggia et al., 2011). The operation considered constraints such as PV power, load demand, SOC of storage and the grid tariffs.

University campuses can often have open areas with relatively unshaded roofs and south facades suitable for building integrated (BI) PV array installation (Talavera et al., 2014; TU Delft, 2018). There are thus large BIPV installations in many university campuses with examples in Greece (Hasapis et al., 2017), Spain (Talavera et al., 2014), Netherlands (TU Delft, 2018), Jordan (Hamzeh et al., 2017), Australia (Islam and Mithulananthan, 2018; Yan et al., 2016) and the USA (Lee et al., 2016; Tian et al., 2014). A 2.25 MWp PV array at the University of Queensland was used to a test a SOC-based EV charging strategy that combined the state of charge (SOC) of EVs with a non-iterative PV output model using real-time measurements and historic PV ramp data (Islam and Mithulananthan, 2018). A smart grid at the Illinois Institute of Technology campus in Chicago, USA included a $20 \mathrm{~kW}$ PV array EV charging station canopy (Tian et al., 2014). In a smart micro-grid campus in Berlin, Germany with $1 \mathrm{MW}$ of battery storage capacity, optimal performance was achieved by combining storage, load curtailment and energy spillage (Wanitschke et al., 2017b). For a $31 \mathrm{kWp} \mathrm{PV} \mathrm{EV} \mathrm{char-}$ ging system a smart controller was developed for bidirectional EV charging that increased self-consumption ratio from $49 \%$ to $87 \%$ to reduce a grid peak demand from $27 \%$ to $67 \%$ (Van Der Kam and Van Sark, 2015). A PV system charging for golf cart EVs in the United Arab Emirates composed of a PV array and a DC-DC buck-boost power converter charged EVs in $8 \mathrm{~h}$ without battery storage or grid extension (Bdwawi et al., 2015). MILP has been applied for optimal EV charging using the real time electricity tariffs (Mouli et al., 2017). An analytical approach to optimize PV EV energy management has been validated via comparison with output from the Transient System Simulation Tool 


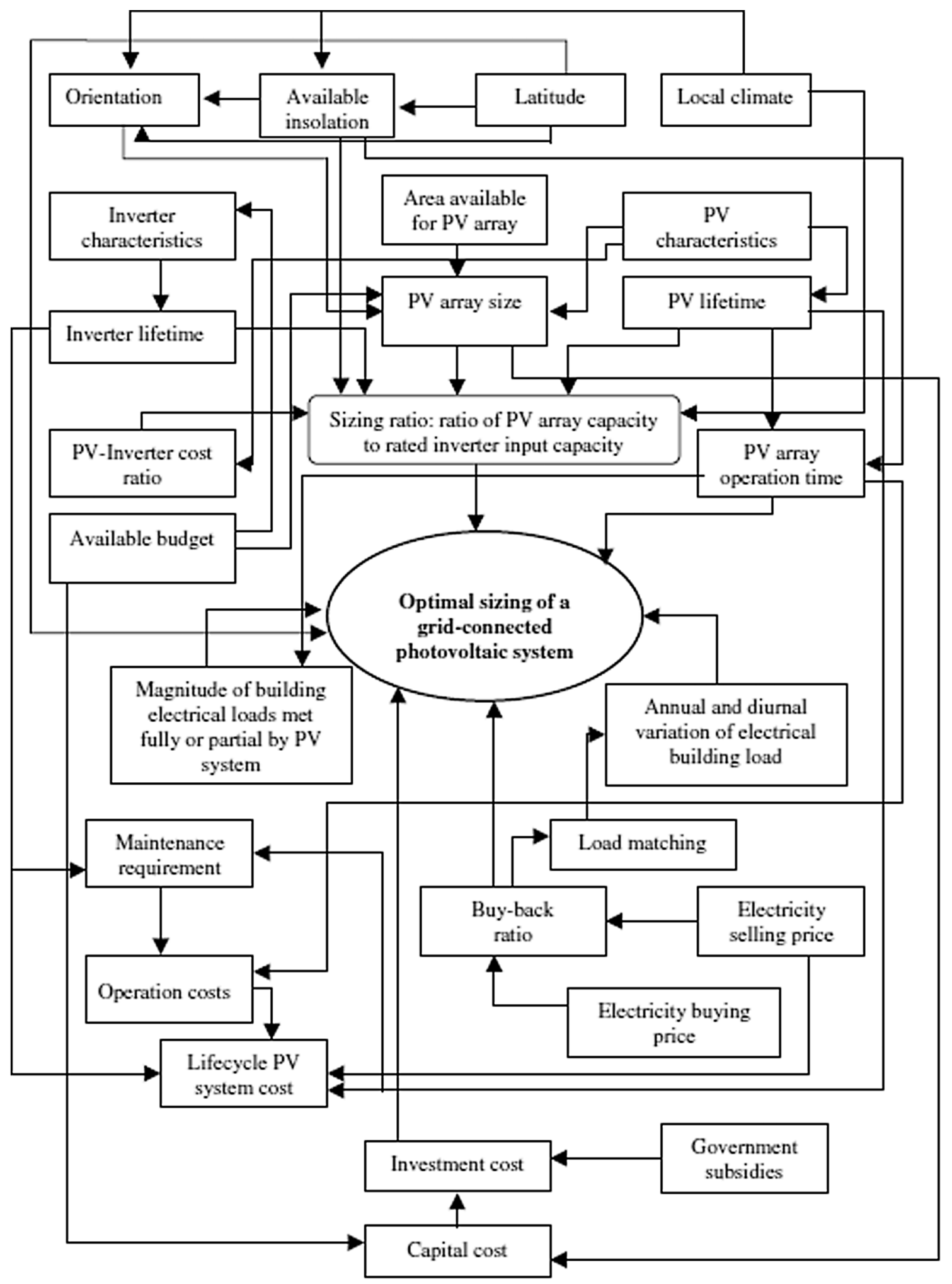

Fig. 1. Factors included in design and performance for campus PV EV charging station (Mondol et al., 2006b).

(TRNSYS) (Esfandyari et al., 2016b).

\section{PV EV charging station design}

An AC coupled $10.5 \mathrm{~kW}, 9.6 \mathrm{kWh}$ battery energy storage PV EV charging station was studied that charged two $13.76 \mathrm{kWh}$ Lightweight Electric Vehicles (LEVs) used on a 73 acre campus for a variety of tasks day and night (Esfandyari et al., 2015a). An energy management controller (EMC) was incorporated to prioritise dispatch flows.

Each LEV (Buggyman Ltd Vehicles, 2018) incorporates eight leadacid batteries with a total capacity of $13.76 \mathrm{kWh}$ recharged via standard three- pin electricity sockets at $230 \mathrm{~V} / 13 \mathrm{~A}$. In the design phase, the energy usage of the LEV's over a day was observed for two months to determine the PV battery system yield required to consistently satisfy 
this demand.

Electricity demand at one minute intervals was measured using current transformers wired to the LEVs grid-fed charging point. Voltage and current profiles were recorded every time a LEV was plugged in a charging point. Table 2 presents the measured demand profile. The average and peak EV load consumptions was 6 and $12 \mathrm{kWh} /$ day respectively for each vehicle.

Four optional PV EV charging station configurations are shown in Fig. 2, which options 1, 2 and 3 have been previously identified and discussed in (Esfandyari et al., 2015a, 2015b). Nonetheless, Option 4 in this study is amended to a fully AC coupled connection between PV, battery and grid.

Option 1, was a direct PV to LEV connection in which the PV array would be the sole source of power. PV panels on the roof of the vehicle provide DC electricity fed directly to the lead acid batteries and/or DC brushed motor. With particularly low average daily winter total solar radiation intensity of $4000 \mathrm{~J} / \mathrm{cm}^{2}$ (Met Éireann, 2018) a demand profile that could reach $13.76 \mathrm{kWh}$ as shown in Table 1 , would require a $11.4 \mathrm{~m}^{2} \mathrm{PV}$ array area on the LEV rooftop. This option was thus discarded as unfeasible (Esfandyari et al., 2015b).

Option 2 was a standalone configuration coupled PV with storage to operate on DC voltage only with generation regulated through a charge controller and stored in a battery. During low solar radiation, the battery would serve as the primary source of energy to meet the load. Due to the absence of any back-up generator, if the discharged battery was not recharged by the PV, the charging station could cease to function. This operational risk makes this option unattractive (Esfandyari et al., 2015b).

Option 3 was a coupled PV-grid without storage that allowed the load to be charged on both DC-AC voltages, depending on available solar radiation. During daytime, PV would be the primary generation. This requires parking the LEVs during sunlight hours to recharge the batteries directly from the PV. During low solar radiation and/or higher demand, the load could be supplied by the utility grid. However, this
Table 1

Specifications of a "CarryAll 500 "LEV.

\begin{tabular}{lll}
\hline & CarryAll 500 Specification \\
\hline \multirow{2}{*}{ Motor } & Type & $48 \mathrm{~V} \mathrm{DC}$ \\
& Rating & $2.7 \mathrm{~kW}$ rated \\
& & Peak $14.9 \mathrm{~kW}$ \\
\multirow{3}{*}{ Speed } & Transmission & Direct $/$ Drive double reduction \\
& Maximum speed & $15 \mathrm{mph}(\sim 25 \mathrm{~km} / \mathrm{h})$ \\
\hline \multirow{2}{*}{ Battery } & Model & Trojan $(\mathrm{T}-145)$ with Flip-Flops $\times 8$ Units \\
& Voltage & $48 \mathrm{~V}(6 \mathrm{~V} \times 8$ Units $)$ \\
& Capacity & $13.76 \mathrm{kWh}(1.72 \mathrm{kWh}$ Each Unit $)$ \\
& & 260 Ah (Each Unit) \\
\hline
\end{tabular}

option would not be feasible, as LEVs used could be charged at night (Esfandyari et al., 2015b).

Option 4 involves AC coupling of a PV array, battery and grid. PV is used during daylight to generate electricity that charges the load, with surplus PV generation stored in the battery. This option was chosen as the battery could be used to charge LEVs, during low or no sunshine periods. Where the batteries are full any surplus in PV generation can be sent to the grid. The grid could also be utilised as a back-up to compensate for generation shortfalls. The inclusion of battery as part of the overall design would enhance the level of solar self-sufficiency and self-consumption ratios. This is thus the preferred option.

The PV array was located on a relatively shadow-free flat roof able to structurally support the array with low wind exposure. As the building chosen was on a vehicle route, it was convenient for EV parking and charging. Average daily LEV demand and average daily solar radiation intensity were the key determinants of PV array size (Khatib, 2010). A LEV daily demand of approximately $30 \mathrm{kWh}$, requires $42,1.63 \mathrm{~m}^{2} 250 \mathrm{~W}$ monocrystalline PV panels, occupying $\sim 69 \mathrm{~m}^{2}$ of the total available south-facing roof area.

To meet the maximum DC voltage input constraint of the inverter to
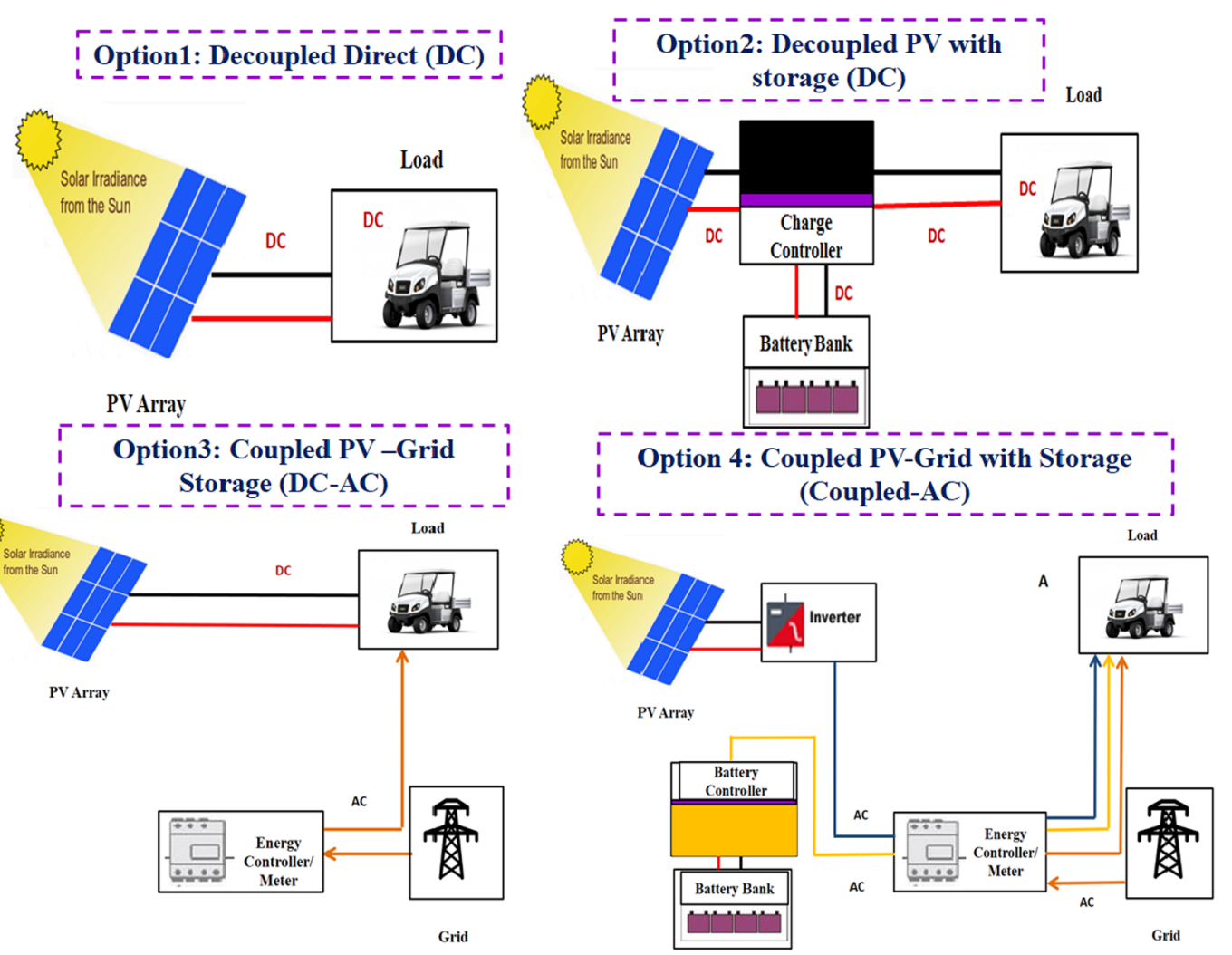

Fig. 2. Schematic diagrams for charging station design options (Esfandyari et al., 2015a, 2015b). 
Table 2

Sample daily EV load profiles (kWh).

\begin{tabular}{|c|c|c|c|c|c|c|c|c|}
\hline & & \multicolumn{7}{|l|}{ Days } \\
\hline & & Monday & Tuesday & Wednesday & Thursday & Friday & Saturday & Sunday \\
\hline \multirow[t]{8}{*}{ Week } & 1 & 2.9 & 0.85 & 2.25 & 4.44 & 4.9 & 1.93 & 4.28 \\
\hline & 2 & 4.34 & 4.43 & 1.62 & 4.45 & 0.53 & 1.15 & 11.85 \\
\hline & 3 & 1.38 & 4.59 & 5.86 & 1.17 & 4.33 & 5.66 & 5.65 \\
\hline & 4 & 6.08 & 3.01 & 2.41 & 3.24 & 3.16 & 5.74 & 4.72 \\
\hline & 5 & 8.04 & 0 & 4.84 & 0 & 6.99 & 0.47 & 4.72 \\
\hline & 6 & 4.2 & 0 & 0 & 0 & 2.98 & 11.95 & 5.283 \\
\hline & 7 & 6.16 & 4.42 & 4.06 & 0.88 & 2.66 & 3.67 & 6.71 \\
\hline & 8 & 0 & 0 & 7.18 & 4.06 & 3.46 & 1.39 & 2.80 \\
\hline
\end{tabular}

which each string was connected, the PV array was divided into two strings of 21 modules, each connected to a $5 \mathrm{~kW}$ maximum AC rating inverter. Each individual string was divided into two substrings connected to a dedicated maximum power point tracker (MPPT), to reduce cable run and ohmic losses. The manufacturer specifications of the monocrystalline silicon PV module installed and the inverter are given in by Table 3 (SMA, 2018; Vikrams, 2018).

The recommended size of the battery depended on the EV load demand and the electricity tariffs. Using a simple payback evaluation, the optimal capacity ranged between $7 \mathrm{kWh}$ and $14 \mathrm{kWh}$. A Lithium-ion battery (LG Chem.) of the capacity range of $9.6 \mathrm{kWh}$ (composed of $6.4 \mathrm{kWh}$ unit with a supplementary $3.2 \mathrm{kWh}$ unit) also outlined in Table 3 was thus used. The battery inverter provides battery energy management (Esfandyari et al., 2016a).

The signalling details for energy management control, communication and sensors are delineated in the dashline area as shown in Fig. 3. The components are: battery energy management (BEM), remote control battery management (RC), radio control smart socket (CS), PV energy meter (EMET), grid meter (GM), energy controller (EC) and web portal.

The overall energy flow is prioritized to maximise self-consumption. The controller receives all the measurement inputs from battery, grid,
PV and load. It dispatches the managed output signals based on the preference priority algorithm. For both load presence and solar radiation availability, PV generated electricity is consumed directly, with any surplus generated energy used to charge the battery or is spilled to the grid. When PV generation is considerably lower than demand, to achieve higher levels of self-consumption, the significant portion of load is accommodated from the battery with the grid used as back-up.

The inverter can be configured to control the system from a central location, where battery charge and discharge signals are communicated automatically via Bluetooth to EC. The measured energy load demand was communicated to the EM via Bluetooth. This allows cost optimisation and/or load shedding, where the control decision is made by EM. EMET and GM components sense the correct phase and balanced electrical measurements, i.e. the measured signals are grid feed-in and purchased electricity meter. These values are sent along with PV generation $\left(\mathrm{E}_{\mathrm{AC}}\right)$, data to the $\mathrm{EM}$.

\section{Performance metrics}

Total calculated daily or monthly energy yield of $E_{D C}$ and $E_{A C}$ were given by Eqs. (1) and (2),

Table 3

System component specifications (SMA; Vikrams, 2018).

\begin{tabular}{|c|c|c|}
\hline P V Array & $\begin{array}{l}\text { Type } \\
\text { Module efficiency } \\
\text { Maximum power }\left(\mathrm{P}_{\max }\right) \\
\text { Maximum power voltage }\left(\mathrm{V}_{\mathrm{mpp}}\right) \\
\text { Maximum power current }\left(\mathrm{I}_{\mathrm{mpp}}\right) \\
\text { Open circuit voltage }\left(\mathrm{V}_{\mathrm{OC}}\right) \\
\text { Short circuit current }\left(\mathrm{I}_{\mathrm{sC}}\right) \\
\text { Temperature coefficient of } \mathrm{P}_{\max } \\
\text { Module area } \\
\text { Number of modules } \\
\text { Number of strings } \\
\text { NOCT } \\
\text { Manufacturer } \\
\text { Inclination } \\
\text { Orientation } \\
\text { Installation type } \\
\text { PV generator surface } \\
\text { Fill factor }\end{array}$ & $\begin{array}{l}\text { Polycrystalline Silicon } \\
15.37 \% \\
250 \mathrm{~W} \\
30.58 \mathrm{~V} \\
8.18 \mathrm{~A} \\
37.45 \mathrm{~V} \\
8.70 \mathrm{~A} \\
-0.415{ }^{\circ} \mathrm{C} \\
1.62 \mathrm{~m}^{2} \\
42 \\
4 \text { strings of } 2 \times 10 \text { and } 2 \times 11 \\
45^{\circ} \mathrm{C} \\
\text { Vikram Solar Pvt Ltc }_{10^{\circ}} \\
\text { Southeast }\left(135^{\circ}\right) \\
\text { Roof Parallel } \\
68.3 \mathrm{~m}^{2} \\
0.76775\end{array}$ \\
\hline Inverter & $\begin{array}{l}\text { Manufacturer } \\
\text { Configuration } \\
\text { Maximum DC power } \\
\text { Maximum AC voltage } \\
\text { Voltage range at MPPT } \\
\text { Efficiency }\end{array}$ & $\begin{array}{l}\text { SMA solar technology AG } 2 \times \text { Sunny Boy 5000TL } \\
\text { (Transformer less) MMP1: } 1 \times 11 \mid \text { MMP2 }: 1 \times 10 \\
5250 \mathrm{~W} \\
5000 \mathrm{~W} \\
500 \mathrm{~V} \\
0.99\end{array}$ \\
\hline Battery & $\begin{array}{l}\text { Manufacturer } \\
\text { BB Inverter } \\
\text { Batteries } \\
\text { Nominal capacity } \\
\text { Weight } \\
\text { Dimension }\end{array}$ & $\begin{array}{l}\text { SMA solar technology AG } \\
\text { SMA Sunny Island 8.0-11 Set -LG Chem } 5.0 \mathrm{kWh} \\
\text { LG Chem }-1 \times \text { LG RESU } 6.4 \mathrm{kWh}+1 \text { unit extension } 3.2 \mathrm{kWh} \\
189 \mathrm{Ah} \\
60 \mathrm{~kg} \\
664 \mathrm{~mm} \times 406 \mathrm{~mm} \times 165 \mathrm{~mm}\end{array}$ \\
\hline
\end{tabular}




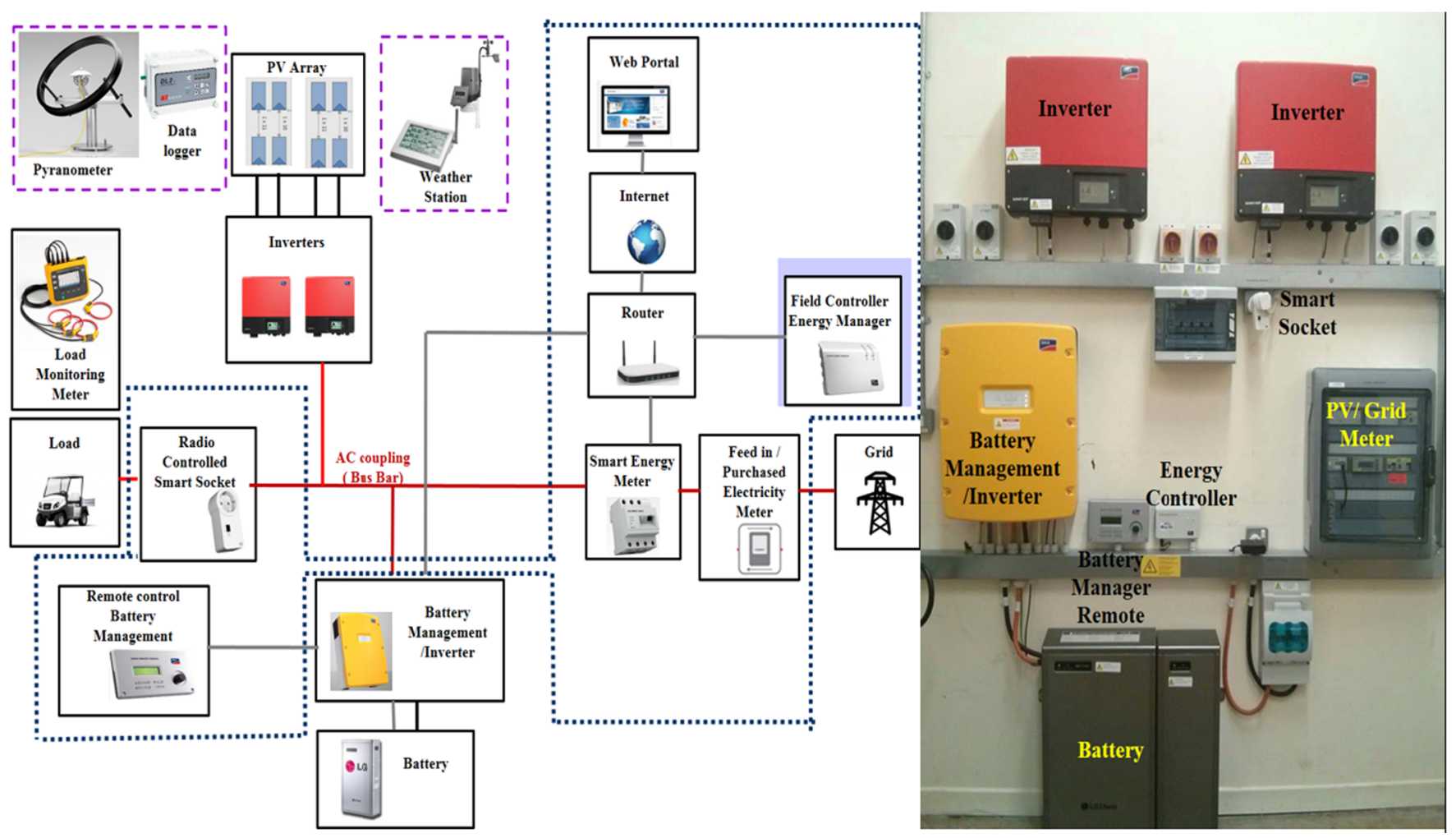

Fig. 3. AC coupled PV-CS components (control and ancillary monitoring sensors) and control room.

$E_{D C \_ \text {Calculated }}(d \mid m)=G_{M} \cdot \mu_{P V}$

$E_{A C_{-} \text {Calculated }}(d \mid m)=E_{D C} \cdot \mu_{\text {Inverter }}$

The difference between field measurements and calculated AC data is given by;

$\%$ diff $\left(E_{A C_{\text {Calculated }}} v E_{A C_{\text {Field }}}\right)=E_{A C_{-} \text {Calculated }}-E_{A C_{\text {_Field }}}$

$$
/\left(E_{A C_{-} \text {Calculated }}+E_{\text {AC_Field }} / 2\right)
$$

A net production matrix can be used to determine the daily/ monthly and annual effectiveness of PV EV charging station (Pless et al., 2005), is given by;

$\%$ PVEffectiveness $(d \mid m)=E_{A C \_C a l c u l a t e d \mid A C \_F i e l d}(\mathrm{~d} \mid \mathrm{m}) / G_{M} * 100 \%$

The array yield $\left(\mathrm{Y}_{\mathrm{A}}\right)$ is the percentage ratio of the average daily $\mathrm{E}_{\mathrm{DC}, \mathrm{d}}$ or monthly $\mathrm{E}_{\mathrm{DC}, \mathrm{m}}$ of the PV EV system $\left(\mathrm{P}_{\mathrm{PV}_{-} \text {rated }}\right)$ is given by;

$Y_{A}(d \mid m(\%))=E_{D C \_ \text {Calculated }}(\mathrm{d} \mid \mathrm{m}) / P_{P V}$ rated

The daily/monthly average final yield, $\left(\mathrm{Y}_{\mathrm{F}}\right)$ enables the comparison of this system to other cases in a specific geographic region. Average final yield is the ratio of the final generation output to the rated Standard Test Conditions (STC), given by;

$Y_{F}(d \mid m(\%))=E_{A C_{-} \text {Calculated } \mid A C_{-} \text {Field }}(\mathrm{d} \mid \mathrm{m}) / P_{P V_{\_} \text {rated }}$

The reference yield is the ratio of the total global $\left(G_{m}\right)$ to the total reference solar radiation on the array, as given by;

$Y_{R}(d \mid m(\%))=\left(G_{M} / G_{S T C}\right)$

Instantaneous system efficiency is defined by Eq. (8), to allow ratio estimation of available solar insolation on the total array area that is converted to the system AC electricity output, as given by;

$\mu_{\text {System }}=\left(E_{A C_{-} \text {Calculated }} / G_{M} \times\right.$ Array area $)$

The overall losses from PV array depends on the solar radiation, PV temperature, shading, PV losses, inverter inefficiencies or failures (Mondol et al., 2006a). The Performance ratio (PR) indicates the proximity of a PV system's output to "ideal" performance that is given by;

$P R=\left(Y_{F} / Y_{R}\right)$

Capacity factor (CF) is the ratio of actual annual output to the amount of energy that the PV system can deliver per day annually. CF varies in proportion to the final yield. When a PV system delivers its full rated power continually, $\mathrm{CF}$ will be close to unity. Capacity factor given by;

$\left.C F=\sum_{d=1}^{N}\left(G_{M} *\left(P R / P_{P V_{-} \text {rated }}\right)\right) * m h\right)$

Array capture losses due to the variation of the actual irradiance from the reference were calculated from;

$L C=Y_{R}-Y_{A}$

PV system losses due to the difference between array yield and final yield result mainly from discontinuity of operation of the inverter over the monitored period. This was calculated from;

$L S=Y_{A}-Y_{F}$

The total quantity of avoided greenhouse gas emissions by PV EV charging system (in $\mathrm{kg} \mathrm{CO} / \mathrm{kWh}$ or tonnes $\mathrm{CO}_{2} / \mathrm{MWh}$ ) replacing the amount of energy purchased from the grid calculated in Eq. (13). To calculate $\mathrm{CO}_{2}$ savings, the monthly $\mathrm{E}_{\mathrm{AC}}$ obtained from field measurement was multiplied by the percentage / fraction of onsite usage of this AC yield $\left(\mathrm{F}_{\mathrm{on}}\right)$, and the average carbon intensity for electricity generated in Ireland ( $\mathrm{ghg}$ Intensity). Hence, The average carbon intensity of the Irish electricity for 2015 was 0.393 tonnes of $\mathrm{CO}_{2}$ per $\mathrm{MWh}$ (Commission for Energy Regulation (CER), 2015).

$G H G_{\text {Avoided }}=E_{A C} * F_{o n} * g h g_{\text {Intesity }}$

The embodied emissions due to the production of the PV system components were not considered (Norton, 1999). 


\section{Annual performance}

IEC61724 procedures were used for measuring and reporting PV array performance (Ayompe et al., 2011b; Mondol et al., 2006a). TRNSYS software was used to simulate the electricity generated by the PV array (Mondol et al., 2009). Experimentally measured solar radiation data provided by the Irish meteorological service (Met Éireann) at one minute intervals was used with horizontal solar radiation data converted to inclined plane solar radiation via a TRNSYS processor.

Fig. 4(A) shows the monthly weather variations including air temperature, rain, ground temperature, wind speed and sunshine divisions with monthly total daily insolation $\left(\mathrm{MJ} / \mathrm{m}^{2}\right)$. As shown in Fig. 4(B), the total daily horizontal insolation was divided into 10 evenly spaced bins, considering the common ratio factor of 1.67 , where approximately $23 \%$ of data was in

the first range.

Table 4 outlines the calculated monthly total daily AC generation $\left(\mathrm{E}_{\mathrm{AC} \_ \text {Field,m }}\right)$, calculated $\mathrm{AC}$ generation $\left(\mathrm{E}_{\mathrm{AC} \_ \text {calculated,m }}\right)$, as well as the diff between field and monitored AC outputs, calculated from Eqs. (1-3). The minimum generation occurred in the month of December, where the maximum output was in May. The average value for $E_{D C, m}$, $\mathrm{E}_{\mathrm{AC}_{-} \text {Field,m }}$ and $\mathrm{E}_{\mathrm{AC}_{-} \text {calculated,m }}$ were $905.1 \mathrm{kWh}, 770.9 \mathrm{kWh}$ and $868.9 \mathrm{kWh}$ respectively, taking into account $15.7 \%$ efficiency losses of array and $0.96 \%$ conversion losses of inverter. Moreover, the annual total DC and AC generated outputs were $1034.4 \mathrm{kWh} / \mathrm{kW}_{\mathrm{p}}$ and $881.1 \mathrm{kWh} / \mathrm{kW}_{\mathrm{p}}$. The percentage conversion error losses between estimated and monitored values of AC-AC are shown in Table 4. As indicated, the average values for percentage conversion loss of

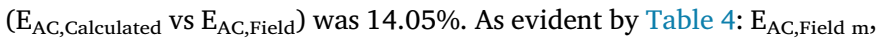

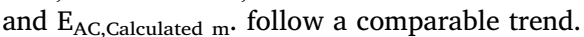

Finally, the annual average value for PV effectiveness for $\left(E_{A C, C a l c u l a t e d}\right)$ that calculated by Eq. (4) was approximately $15.1 \%$, as it considered the efficiency losses of both DC and AC.

Table 5 presents the system efficiency, average daily, final and reference yields (PSH) of the PV system during the monitoring period, as described by Eqs. (5-7). Average efficiency of the system ( $\left.\mu_{\text {System }}\right)$ using Eq. (8), was found $13.4 \%$.

The monthly average daily array yield varied between $0.5 \mathrm{~h}$ per day (h/d) to $5.3(\mathrm{~h} / \mathrm{d})$ in December 2016 and May 2017 respectively. Subsequently the monthly average daily final yield $\left(\mathrm{E}_{\mathrm{AC} \text {,Field } \mathrm{m}}\right)$ occurred at $0.46(\mathrm{~h} / \mathrm{d})$ to $4.62(\mathrm{~h} / \mathrm{d})$ for the same months. Finally, the reference yield ranged from $0.49(\mathrm{~h} / \mathrm{d})$ to $5.18(\mathrm{~h} / \mathrm{d})$, where the averaged PSH for Dublin, Ireland was estimated to be approximately 2.72 .
Table 4

Energy output, percentage conversion loss and PV effectiveness.

\begin{tabular}{lllll}
\hline & $\mathrm{E}_{\mathrm{DC}, \mathrm{m}}$ & $\mathrm{E}_{\mathrm{AC} \_ \text {Field,m }}$ & $\mathrm{E}_{\mathrm{AC} \_ \text {calculated-m }}$ & \%diff \\
\hline August & 1263.2 & 1094.53 & 1212.67 & 10.241 \\
September & 909.41 & 776.81 & 873.03 & 11.66 \\
October & 646.70 & 498.84 & 620.83 & 21.79 \\
November & 394.51 & 291.12 & 378.72 & 26.15 \\
December & 165.33 & 152.06 & 158.71 & 4.28 \\
January & 256.46 & 180.37 & 246.20 & 30.86 \\
February & 363.70 & 310.50 & 349.152 & 11.71 \\
March & 895.862 & 750.713 & 860.028 & 13.57 \\
April & 1052.48 & 932.22 & 1010.38 & 8.04 \\
May & 1726.38 & 1505.32 & 1657.32 & 9.61 \\
June & 1572.21 & 1347.48 & 1509.32 & 11.32 \\
July & 1615.07 & 1411.39 & 1550.40 & 9.38 \\
Average & 905.106 & 770.94 & 868.9 & 14.05 \\
\hline
\end{tabular}

Table 5

Array, Final and Reference Yield variations.

\begin{tabular}{|c|c|c|c|c|c|}
\hline & & $\mu_{\text {System }}(\%)$ & $\begin{array}{l}\text { Array yield }(\mathrm{h} / \mathrm{d}) \\
\text { to the rated } \\
10.5 \mathrm{~kW} \text { power }\end{array}$ & $\begin{array}{l}\text { Final } \\
\text { yield (h/ } \\
\text { d) }\end{array}$ & $\begin{array}{l}\text { Reference } \\
\text { yield }(\mathrm{h} / \mathrm{d})\end{array}$ \\
\hline \multirow[t]{12}{*}{ Month } & August & 13.63 & 3.88 & 3.36 & 3.79 \\
\hline & September & 13.44 & 2.88 & 2.46 & 2.82 \\
\hline & October & 12.14 & 1.98 & 1.53 & 1.94 \\
\hline & November & 12.03 & 1.25 & 0.92 & 1.18 \\
\hline & December & 14.65 & 0.5 & 0.46 & 0.49 \\
\hline & January & 11.04 & 0.78 & 0.55 & 0.77 \\
\hline & February & 14.88 & 1.23 & 1.05 & 1.09 \\
\hline & March & 13.22 & 2.75 & 2.30 & 2.68 \\
\hline & April & 14.39 & 3.34 & 2.95 & 3.16 \\
\hline & May & 13.72 & 5.30 & 4.62 & 5.18 \\
\hline & June & 13.93 & 4.99 & 4.277 & 4.72 \\
\hline & July & 13.77 & 5.12 & 4.48 & 4.84 \\
\hline Average & & 13.40 & 2.83 & 2.415 & 2.72 \\
\hline
\end{tabular}

Fig. 5 shows the data in Table 5 graphically as well as the variation of PR and CF as defined by Eqs. (9) and (10). The annual average daily PR ratio was $87 \%$, where the minimum and maximum range varied between $71 \%$ and $93 \%$. This minimum value was due to lower solar intensity $\left(0.77 \mathrm{~W} / \mathrm{m}^{2}\right)$, which impacted the reference yield and subsequently PR. CF percentage varied between $2 \%$ and $19.2 \%$ with an average of $10 \%$. Fig. 5 also shows the monthly average array capture losses and system losses over the monitored period. As calculated by
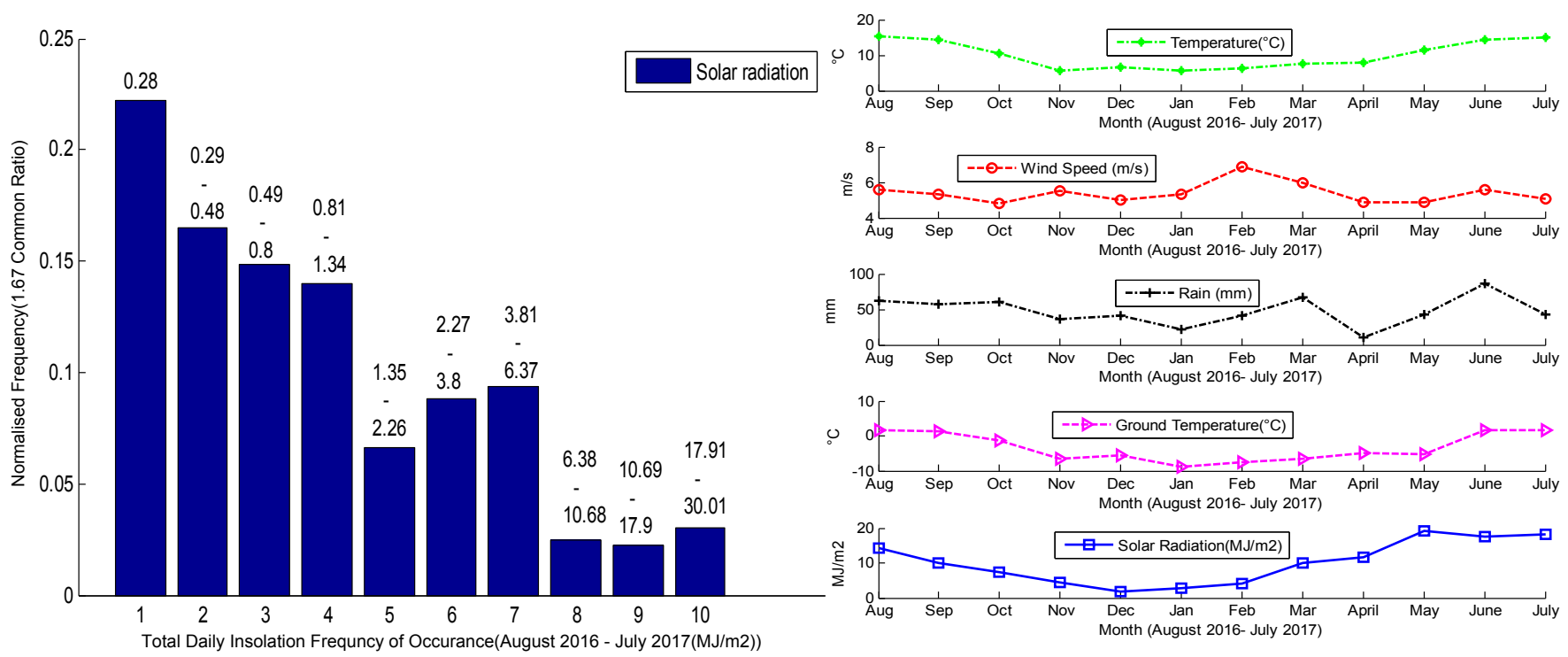

Fig. 4. Climate at the location of PV array. 

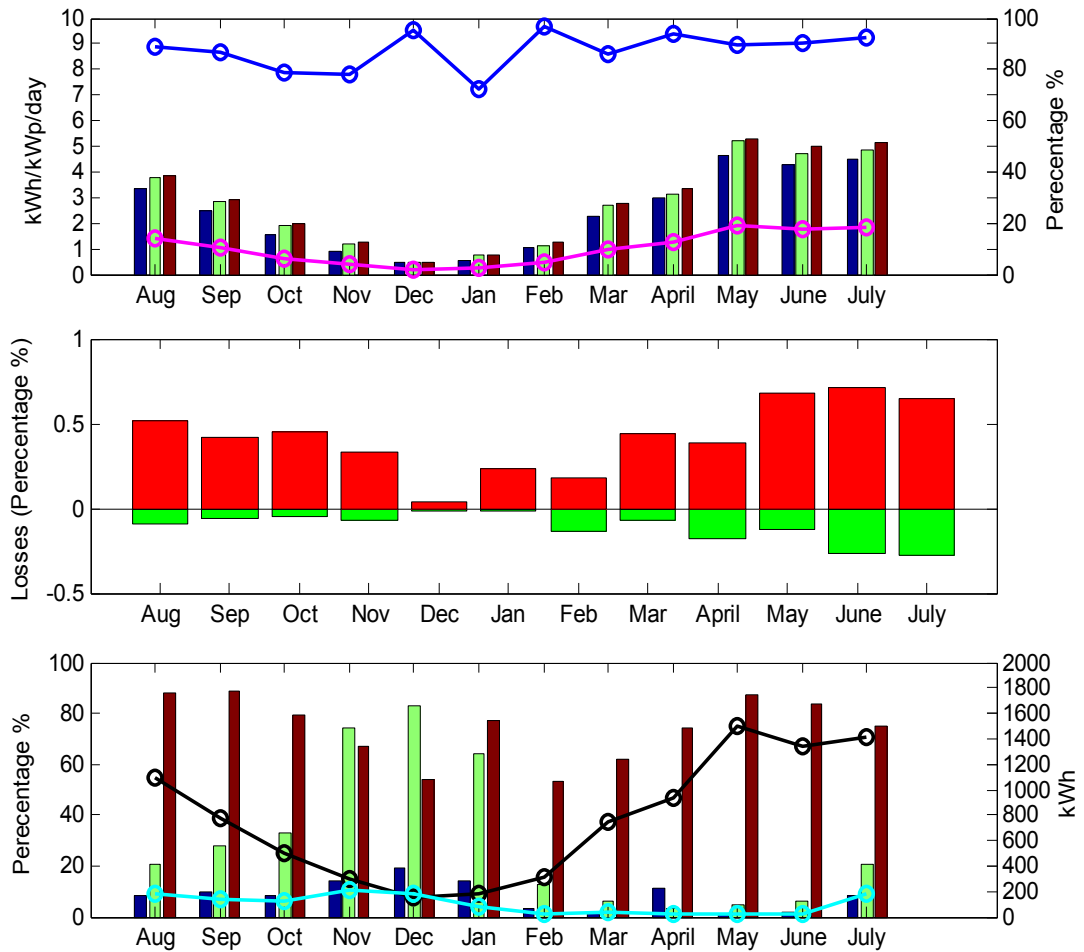
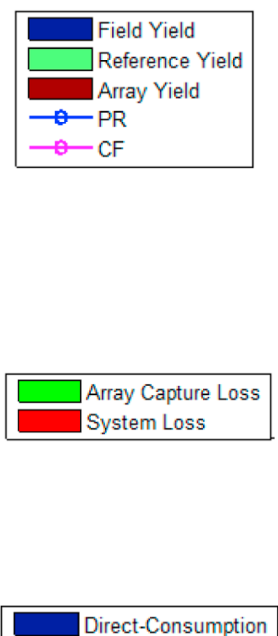
Self-Consumption $\square$ Self-Sufficiency Q-Field Generation C-Field Consumption

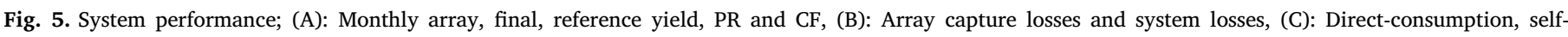
consumption, self-sufficiency, field generation and field consumption.

Table 6

$\mathrm{CO}_{2}$ saving, direct consumption, self-consumption and self-sufficiency.

\begin{tabular}{lllll}
\hline & $\begin{array}{l}\text { Direct } \\
\text { consumption } \\
(\%)\end{array}$ & $\begin{array}{l}\text { Self- } \\
\text { consumption } \\
(\%)\end{array}$ & $\begin{array}{l}\text { Self- } \\
\text { sufficiency } \\
(\%)\end{array}$ & $\begin{array}{l}\text { GHG } \\
\text { avoided } / \mathrm{CO}_{2} \\
\text { saving }(\mathrm{kg})\end{array}$ \\
\hline August & 8 & 21 & 88 & 430.153 \\
September & 10 & 28 & 89 & 305.287 \\
October & 8 & 33 & 79 & 196.047 \\
November & 14 & 74 & 67 & 114.407 \\
December & 19 & 83. & 54 & 59.757 \\
January & 14 & 64 & 77 & 70.888 \\
February & 3 & 13 & 53 & 122.029 \\
March & 2 & 6 & 62 & 295.03 \\
April & 11 & 3 & 74 & 366.36 \\
May & 1 & 5 & 87 & 591.59 \\
June & 2 & 6 & 84 & 529.56 \\
July & 8 & 21 & 75 & 554.67 \\
Average & 8 & 30 & 74 & 302.98 \\
\hline
\end{tabular}

Table 7

Annual variation of $\mathrm{CO}_{2}$ emission and tax savings (AC coupled Campus PV EV charging).

\begin{tabular}{lllll}
\hline & \multicolumn{2}{l}{$\begin{array}{l}\mathrm{E}_{\mathrm{AC}} \text { consumed onsite } \\
\mathrm{kWh}\end{array}$} & $\begin{array}{l}\mathrm{GHG}_{\text {avoided }} \\
\text { Tonnes }\end{array}$ & $\begin{array}{l}\mathrm{GHG}_{\text {avoided }} \\
€ / / \text { tonnes }\end{array}$ \\
\hline $\mathrm{f}_{\text {on }}(\%)$ & 100 & 9251.353 & 3.63 & 72.72 \\
& 80 & 7401.09 & 2.9 & 58.18 \\
60 & 5550.81 & 2.18 & 43.29 \\
40 & 3700.54 & 1.45 & 29.09 \\
20 & 1850.27 & 0.72 & 14.54 \\
\hline
\end{tabular}

Eqs. (11) and (12), array capture losses varied between -0.018 in December/January and -0.28 in July. The system losses fluctuated between minimum of 0.04 in December and maximum of 0.71 in the month of June.

Table 6 presents the monthly variation for direct consumption, self-
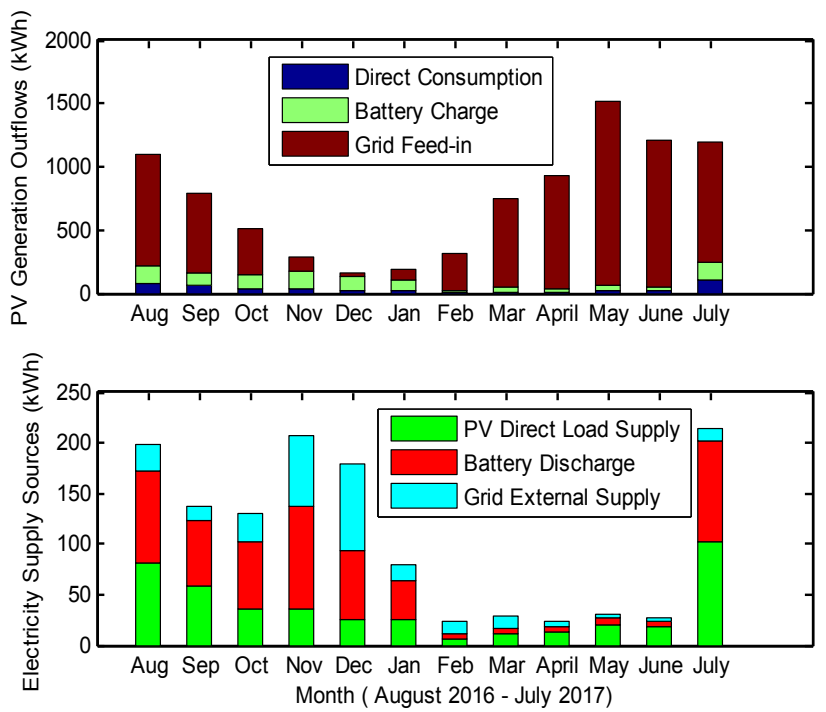

Fig. 6. Electricity flows.

consumption and self-sufficiency along with $\mathrm{CO}_{2}$ savings. The combination of PV and battery with smaller load demand, resulted in a high level of system self-sufficiency. The self-consumption ratio over the months of November, December and January was high, 74\%, 83\% and $64 \%$ respectively.

As indicated by the black line in Fig. 5, PV generation at the starting month of winter period (September) was around $1094.5 \mathrm{kWh}$. The output gradually decreased and experienced the lowest generation of $152 \mathrm{kWh}$ in December. Output increased significantly in the summer period with the maximum generation output of $1411 \mathrm{kWh}$. LEV total demand at the start of the annual period (August) was around $177 \mathrm{kWh}$. This value increased in November $(206 \mathrm{kWh})$. Hence, this increase emerged due to the colder weather conditions, which encouraged the users to utilise LEVs more frequently. In December as the campus was 
less occupied in the winter holiday season, this value was only $179.1 \mathrm{kWh}$. In February-June users solely drew from the grid. As a result, the calculation for the average daily LEV load consumption took into account the active period only which was estimated at around $5.74 \mathrm{kWh}$.

\section{Discussion and future work}

A PV system cost and benefits can be appraised from financial and environmental aspects (Ayompe et al., 2010; Ramadhan and Naseeb, 2011). The level of $\mathrm{CO}_{2}$ savings were estimated using Eq. (13) for $100 \%$ on-site usage of $\mathrm{E}_{\mathrm{AC}}$, i.e., as the key benefit of the AC coupled design is that can allow promoting $100 \% \mathrm{PV}$ utilisation. Maximum $\mathrm{CO}_{2}$ savings of $591.6 \mathrm{~kg}$ occurred in May 2016. Table 7 shows the variation of fraction of PV generation used onsite $\left(\mathrm{f}_{\text {on }}\right)$ and its impacts on the annual $\mathrm{E}_{\mathrm{AC}}$ consumed onsite $(\mathrm{kWh})$, i.e., for the field monitored generation outputs and a ghg intensity of 0.393 (tonnes). The Commission for Taxation in Ireland has assigned GHG tax receipts of $20 € / /$ tonnes to energy production of solid fuel (Department of Finance, 2017). The estimated GHG avoided resulted in both $\mathrm{CO}_{2}$ emission and tax saving. In other words, AC coupled design could result in $3635.78 \mathrm{~kg}$ of avoided GHG and $\sim 73$ euros on $\mathrm{CO}_{2}$ tax.

Future work would consider simulation of energy management controller with two distinct load and battery priorities that could consequently optimize the energy dispatch and GHG savings potentials. Further comparison between field and simulated could be conducted. The cost benefit analyses would be extended to estimate the payback and net present value of the installation, and impact of different PV and battery sizes on economic indicators.

\section{Conclusions}

This paper discusses the adopted procedure for design of an AC coupled campus PV EV charging station, while the results obtained from monitoring the PV EV charging infrastructure in a university campus in Dublin, Ireland between August 2016 and July 2017 have been presented. The deployed AC coupled campus charging infrastructure can offer $100 \%$ percentage on-site electricity use. The annual unsubsidized excess of PV yield results in $\mathrm{CO}_{2}$ emission and tax savings of up to $3635.78 \mathrm{~kg} / \mathrm{kWh}$ and 73 euro/tonnes regularly. The annual average daily final yield, array yield and reference yield were $2.41,2.83$ and $2.72 \mathrm{kWh} / \mathrm{kW}_{\mathrm{p}} /$ day respectively. Moreover the annual average daily performance ratio and capacity factor were $87 \%$ and $10 \%$ respectively. Annual average PV electricity generation efficiency was $13.5 \%$. The maximum $1442.8 \mathrm{kWh}$ grid feed-in occurred in May, while both the peak battery charge of $145 \mathrm{kWh}$ and discharge of $101 \mathrm{kWh}$ took place in November. Fig. 6 shows that overall LEV consumption which were dispatched by field energy controller. The demand could be met by a combined dispatch via direct consumption, battery discharge and grid supply. From November to January, when the load was active and the solar intensity low, battery discharge and the grid accommodated the EV load, so system self-sufficiency was much lower at $67 \%$ in November and 57\% in December. During the peak generation month of May, the PV EV charging station had higher level of self-sufficiency $(88 \%)$ with lower self-consumption ratios of only $4 \%$.

\section{Acknowledgments}

Authors would like to acknowledge support from a Fiosraigh scholarship in Dublin Institute of Technology, and Trinity College Dublin for collabration support.

\section{References}

Ayompe, L.M., Duffy, A., McCormack, S.J., Conlon, M., 2011a. Measured performance of a $1.72 \mathrm{~kW}$ rooftop grid-connected photovoltaic system in Ireland. Energy Convers.
Manage. 52, 816-825.

Ayompe, L.M., Duffy, A., McCormack, S.J., Conlon, M., 2011b. Performance and Policy Evaluation of Solar Energy Technologies for Domestic Application in Ireland $(\mathrm{PhD}$ thesis). Dublin Institute of Technology.

Ayompe, L.M., Duffy, A., McCormack, S.J., Conlon, M., 2010. Projected costs of a gridconnected domestic PV system under different scenarios in Ireland, using measured data from a trial installation. Energy Policy 38, 3731-3743. https://doi.org/10.1016/ j.enpol.2010.02.051.

Bdwawi, A. Al, Ahbabi, H. Al, Shamsi, S.A. Al, Hussein, A.a., 2015. Modular photovoltaic charging station for UAE university golf carts. Energy Procedia 75, 314-318.

Bertsch, V., Geldermann, J., Lühn, T., 2017. What drives the profitability of household PV investments, self-consumption and self-sufficiency? Appl. Energy 204, 1-15.

Bhatti, A.R., Salam, Z., Aziz, M.J.B.A., Yee, K.P., Ashique, R.H., 2016. Electric vehicles charging using photovoltaic: status and technological review. Renew. Sustain. Energy Rev. 54, 34-47. https://doi.org/10.1016/j.rser.2015.09.091.

Birnie, D.P., 2009. Solar-to-vehicle (S2V) systems for powering commuters of the future. J. Power Sources 186, 539-542.

Chandra Mouli, G.R., 2018. Charging Electric Vehicles from Solar Energy Power Converter, Charging Algorithm and System Design. TU Delft Univ. Delft University of Technology. https://doi.org/10.4233/uuid.

Codani, P., Portz, P.L. Le, Claverie, P., Perez, Y., Petit, M., 2015. Coupling local renewable energy production with electric vehicle charging: a survey of the French case. World Electr. Veh. J. 7, 489-499. https://doi.org/10.1504/IJATM.2016.076443.

Commission for Energy Regulation (CER), 2015. Fuel mix disclosure and CO2 emissions 2015.

Delfanti, M., Falabretti, D., Merlo, M., 2015. Energy storage for PV power plant dispatching. Renew. Energy 80, 61-72. https://doi.org/10.1016/j.renene.2015.01.047.

Department of Finance, 2017. Energy and Environmental Taxes Tax Strategy Group- TSG. Dublin.

Esfandyari, A., Norton, B., Conlon, M., McCormack, S.J., 2016a. Energy managment of photovoltaic charging station (PV-CS) for green university campus transportation. Irish Transport Research Netwoerk (ITRN). Dublin, Ireland.

Esfandyari, A., Norton, B., Conlon, M., McCormack, S.J., 2015a. Essentials for on-campus photovoltaic charging station (PV-CS): Grangegorman. Irish Transport Research Network (ITRN). Galway, Ireland.

Esfandyari, A., Norton, B., Conlon, M., McCormack, S.J., 2015b. The battery energy storage system (BESS) design option for on-campus photovoltaic charging station (PV-CS). In: Solar World Congress. International Solar Energy Society ISES, Daegu, Korea, pp. 8-12.

Esfandyari, A., Swierc, A., Norton, B., Conlon, M., McCormack, S.J., 2016b. Modelling and energy management optimisation of battery energy storage system (BESS) based photovoltaic charging station (PV-CS) for university campus. In: Photovoltaic Solar Energy Conference and Exhibition. EU PVSEC, Munich, Germany. https://doi.org/10. 1017/CBO9781107415324.004.

Foley, A.M., Winning, I.J., Gallachóir, B.P.Ó., 2010. State-of-the-art in electric vehicle charging infrastructure. In: 2010 IEEE Veh. Power Propuls. Conf. VPPC 2010, https:// doi.org/10.1109/VPPC. 2010.5729014.

Goli, P., Shireen, W., 2015. Control and management of PV integrated charging facilities for PEVs. In: Plug In, Electric Vehicles in Smart Grids. Springer, pp. 23-54. https:// doi.org/10.1007/978-981-287-317-0.

Goli, P., Shireen, W., 2014. PV powered smart charging station for PHEVs. Renew. Energy 66, 280-287. https://doi.org/10.1016/j.renene.2013.11.066.

Gurkaynak, Y., Li, Z., Khaligh, A., 2009. A novel grid-tied, solar powered residential home with plug-in hybrid electric vehicle (PHEV) loads. In: 5th IEEE Vehicle Power and Propulsion Conference, VPPC, pp. 813-816. https://doi.org/10.1109/VPPC.2009. 5289765.

Hamzeh, A., Hamid, S., Sandouk, A., Al-Omari, Z., Aldahim, G., 2017. First-year performance of a PV plant in Jordan compared to PV plants in the region. Int. J. Renew. Energy Res. 5, 785-798. https://doi.org/10.1007/978-3-319-30746-6 61.

Hasapis, D., Savvakis, N., Tsoutsos, T., Kalaitzakis, K., Psychis, S., Nikolaidis, N.P., 2017. Design of large scale prosuming in Universities: the solar energy vision of the TUC campus. Energy Build. 141, 39-55. https://doi.org/10.1016/j.enbuild.2017.01.074.

Islam, M.S., Mithulananthan, N., 2018. PV based EV charging at universities using supplied historical PV output ramp. Renew. Energy 118, 306-327. https://doi.org/10. 1016/j.renene.2017.11.009.

Khatib, T., 2010. A review of designing, installing and evaluting standalone PV power systems. Appl. Sci. 10, 1212-1228.

Kineavy, F., Duffy, M., 2014. Modelling and design of electric vehicle charging systems that include on-site renewable energy sources. In: Power Electronics for Distributed Generation Systems (PEDG), 2014 IEEE 5th International Symposium On. IEEE, https://doi.org/10.1109/PEDG.2014.6878651.

Kusakana, K., 2017. Energy management of a grid-connected hydrokinetic system under time of use tariff. Renew. Energy 101, 1325-1333. https://doi.org/10.1016/j.renene. 2016.10.019.

Kymakis, E., Kalykakis, S., Papazoglou, T.M., 2009. Performance analysis of a grid connected photovoltaic park on the island of Crete. Energy Convers. Manage. 50, 433-438. https://doi.org/10.1016/j.enconman.2008.12.009.

Lee, J., Chang, B., Aktas, C., Gorthala, R., 2016. Economic feasibility of campus-wide photovoltaic systems in New England. Renew. Energy 99, 452-464. https://doi.org/ 10.1016/j.renene.2016.07.009.

Lorenzi, G., Silva, C.A.S., 2016. Comparing demand response and battery storage to optimize self-consumption in PV systems. Appl. Energy 180, 524-535. https://doi.org/ 10.1016/j.apenergy.2016.07.103.

Luthander, R., Widen, J., Nilsson, D., Palm, J., 2015. Photovoltaic self-consumption in buildings: a review. Appl. Energy 142, 80-94. https://doi.org/10.1016/j.apenergy 2014.12.028. 
Met Éireann, 2018. Met Éireann - The Irish Weather Service [WWW Document]. URL https://www.met.ie/climate/dublinairport.asp (accessed 3.10.18).

Mondol, J.D., Yohanis, Y., Smyth, M., Norton, B., 2006a. Long term performance analysis of a grid connected photovoltaic system in Northern Ireland. Energy Convers. Manage. 47, 2925-2947. https://doi.org/10.1016/j.enconman.2006.03.026.

Mondol, J.D., Yohanis, Y.G., Norton, B., 2009. Optimising the economic viability of gridconnected photovoltaic systems. Appl. Energy 86, 985-999. https://doi.org/10. 1016/j.apenergy.2008.10.001.

Mondol, J.D., Yohanis, Y.G., Norton, B., 2007. Comparison of measured and predicted long term performance of grid a connected photovoltaic system. Energy Convers. Manage. 48, 1065-1080. https://doi.org/10.1016/j.enconman.2006.10.021.

Mondol, J.D., Yohanis, Y.G., Norton, B., 2006b. Optimal sizing of array and inverter for grid-connected photovoltaic systems. Solar Energy 80, 1517-1539. https://doi.org/ 10.1016/j.solener.2006.01.006.

Mouli, G.R.C., Bauer, P., Zeman, M., 2016. System design for a solar powered electric vehicle charging station for workplaces. Appl. Energy 168, 434-443. https://doi.org/ 10.1016/j.apenergy.2016.01.110

Mouli, G.R.C., Bauer, P., Zeman, M., 2015. Comparison of system architecture and converter topology for a solar powered electric vehicle charging station. In: 9th International Conference on Power Electronics-ECCE Asia. Seoul, Korea, pp. 1908-1915. https://doi.org/10.1109/ICPE.2015.7168039.

Mouli, G.R.C., Kefayati, M., Baldick, R., Bauer, P., 2017. Integrated PV charging of EV fleet based on energy prices, V2G and offer of reserves. IEEE Trans. Smart Grid 3053https://doi.org/10.1109/TSG.2017.2763683. 11.

Norton, B., 1999. Renewable electricity - what is the true cost? Power Eng J. 13, 6-12. https://doi.org/10.1049/pe:19990104.

Nyholm, E., Goop, J., Odenberger, M., Johnsson, F., 2016. Solar photovoltaic-battery systems in Swedish households - self-consumption and self-sufficiency. Appl. Energy 183, 148-159. https://doi.org/10.1016/j.apenergy.2016.08.172.

Pless, S.P., Deru, M., Torcellini, P., Hayter, S., 2005. Procedure for Measuring and Reporting the Performance of Photovoltaic Systems in Buildings, National Renewable Energy Laboratory (NREL). Golden, Colorado, USA.

LG chem RESU 6.4 data sheet [Online]. Available: http://www.lgchem.com/global/ess/ ess/product-detail-PDEC0001.

Ramadhan, M., Naseeb, A., 2011. The cost benefit analysis of implementing photovoltaic solar system in the state of Kuwait. Renew. Energy 36, 1272-1276. https://doi.org/ 10.1016/j.renene.2010.10.004.

Riffonneau, Y., Bacha, S., Barruel, F., Ploix, S., 2011. Optimal power flow management for grid connected PV systems with batteries. IEEE Trans. Sustain. Energy 309-320. https://doi.org/10.1109/TSTE.2011.2114901.

Roggia, L., Rech, C., Schuch, L., Baggio, J.E., Hey, H.L., Pinheiro, J.R., 2011. Design of a sustainable residential microgrid system including PHEV and energy storage device. In: 14th European Conference on Power Electronics and Applications, pp. 1-9. https://doi.org/10.1109/TSG.2014.2318836.

SEAI, 2017. Electricity \& Gas Prices in Ireland - 2016. Dublin.

SMA SUNNY BOY 3000TL / 4000TL / 5000TL datasheet [Online]. Available: http:// www.sma.de/en/products/solarinverters.

Speidel, S., Bräunl, T., 2016. Leaving the grid-The effect of combining home energy storage with renewable energy generation. Renew. Sustain. Energy Rev. 60 1213-1224. https://doi.org/10.1016/j.rser.2015.12.325.

Sundaram, S., Babu, J.S.C., 2015. Performance evaluation and validation of 5MWp grid connected solar photovoltaic plant in South India. Energy Convers. Manage. 100,
429-439. https://doi.org/10.1016/j.enconman.2015.04.069.

Talavera, D.L., De La Casa, J., Munoz-Ceron, E., Almonacid, G., 2014. Grid parity and selfconsumption with photovoltaic systems under the present regulatory framework in Spain: the case of the University of Jaen Campus. Renew. Sustain. Energy Rev. 33, 752-771. https://doi.org/10.1016/j.rser.2014.02.023.

Tamis, M., Hoed, R., Den, V., Thorsodottir, H., 2017. Smart charging in Netherlands. In: European Battery, Hybird \& Electric Fuel Cell Electric Vehicle Congress. Geneva, pp. $14-16$.

Tian, W., Jiang, Y., Shahidehpour, M., Krishnamurthy, M., 2014. Vehicle charging stations with solar canopy: a realistic case study within a smart grid environment. In: IEEE Transportation Electrification Conference and Expo (ITEC), pp. 1-6. https://doi. org/10.1109/ITEC.2014.6861801.

Tie, S.F., Tan, C.W., 2013. A review of energy sources and energy management system in electric vehicles. Renew. Sustain. Energy Rev. 20, 82-102. https://doi.org/10.1016/ j.rser.2012.11.077.

Torreglosa, J.P., García-triviño, P., Fernández-ramirez, L.M., Jurado, F., 2016. Decentralized energy management strategy based on predictive controllers for a medium voltage direct current photovoltaic electric vehicle charging station. Energy Convers. Manage 108, 1-13. https://doi.org/10.1016/j.enconman.2015.10.074.

TU Delft, 2018. PV system design [WWW Document]. URL https://www.tudelft.nl/en/ eemcs/the-faculty/departments/electrical-sustainable-energy/photovoltaicmaterials-and-devices/dutch-pv-portal/the-model/pv-system-design/ (accessed 7. 18.17).

Tulpule, P.J., Marano, V., Yurkovich, S., Rizzoni, G., 2013. Economic and environmental impacts of a PV powered workplace parking garage charging station. Appl. Energy 108, 323-332. https://doi.org/10.1016/j.apenergy.2013.02.068.

University of Iowa, 2018. Electric vehicle charging station - solar energy - renewable energy - facilities management [WWW Document]. URL http://facilities.uiowa.edu/ uem/renewable-energy/solar-energy.html (accessed 1.24.18).

Van Der Kam, M., Van Sark, W., 2015. Smart charging of electric vehicles with photovoltaic power and vehicle-to-grid technology in a microgrid; a case study. Appl. Energy 152, 20-30. https://doi.org/10.1016/j.apenergy.2015.04.092.

Van Der Stelt, S., AlSkaif, T., Van Sark, W., 2018. Techno-economic analysis of household and community energy storage for residential prosumers with smart appliances. Appl. Energy 209, 266-276. https://doi.org/10.1016/j.apenergy.2017.10.096.

Vehicles, C.U., 2018. Carryall Utility Vehicles | The BUGGYMAN [WWW Document]. URL http://www.buggyman.net/products/utility-box-vehicles (accessed 7.31.15).

Vikrams, 2018. Data Sheets - Vikram Solar [WWW Document]. URL https://www. vikramsolar.com/download-category/data-sheets/ (accessed 6.13.18).

Wanitschke, A., Pieniak, N., Schaller, F., 2017a. Economic and environmental cost of selfsufficiency - analysis of an urban micro grid. Energy Procedia. 445-451. https://doi. org/10.1016/j.egypro.2017.09.510.

Wanitschke, A., Pieniak, N., Schaller, F., 2017b. Economic and environmental cost of selfsufficiency-analysis of an urban micro grid. Energy Procedia 135, 445-451. https:// doi.org/10.1016/j.egypro.2017.09.510.

Weniger, J., Tjaden, T., Quaschning, V., 2014. Sizing of residential PV battery systems. Energy Procedia 46, 78-87. https://doi.org/10.1016/j.egypro.2014.01.160.

Yan, R., Saha, T.K., Meredith, P., Ananth, A., Hossain, M.I., 2016. Megawatt-scale solar variability study: an experience from a 1.2 MWp photovoltaic system in Australia over three years. IET Renew. Power Gener. 10, 1229-1236. https://doi.org/10.1049/ iet-rpg.2015.0383. 